\title{
The Role of Indigenous Products in Cosmetology from Ancient to Modern Times
}

\author{
Lakmali Pathiraja K $\mathrm{N}^{*}$ \\ Consultant Dermatologist, Ministry of Health, Nutrition and Indigenous Medicine, Sri Lanka
}

Submission: May 15, 2018; Published: August 29, 2018

*Corresponding author: Lakmali Pathiraja K N, Consultant Dermatologist, Ministry of Health, Nutrition and Indigenous Medicine, Sri Lanka, Email: pathirajaknl@gmail.com

Abstract

People of Indian, Sri Lankan, Pakistanian and Malaysian origin belongs to the "Dark Asian" Ethnic Skin Type. Although, a large proportion of subjects belong to this category, literature is limited except for a few studies that focuses on pigmentation. However, traditional skin concerns on various ethnic groups will enhance modern treatment strategies of various skin types.

The Sri Lankan indigenous medicinal system is unique. Thousands of years of history has made it evident that this system has a treatment for any illness, including rare dermatological conditions. There is a rich collection of medicinal plants and herbal products, which have been used for ages for cutaneous treatment, skin care and aesthetic purposes [1]. As there is a lack of modern research on skin care and the treatment of this skin type, secrets of ancient skin will promote the effectiveness of current skin care and treatments for this ethnic skin type.

Keywords: Skin; Pigmentation; Cutaneous; Treatment; Sweat glands; Epidermal water loss; Turmeric

\section{Introduction}

"Ethnic skin" is the broad term given to skin types according to genetic links of specific ethnic groups. Furthermore, various environmental, cultural and social factors related to ethnicity have a great impact on skin.

There are six major ethnic skin types; White Skin, Mediterranean Skin, Light Asian Skin, Dark Asian Skin, Africo Caribbean Skin and Mixed Skin [2]. Asians comprise about half of the world's population today, though literature concerning their skin is lacking. However, during the past few decades, issues regarding the differences of the structure and function of Asian skin were raised in the industry of skin care products.

Asian skin is pigmented, has larger sweat glands and is smooth, and more prone to comedowns. It has a thicker dermis with large collagen bundles, and shows minimal Signs of aging, but conversely the epidermis is thinner, and has higher trans epidermal water loss [TEWL] and weaker barrier function upon chemical or mechanical challenge [2,3]. Furthermore, they hold higher risk of pigmentary side effects following procedures carried out on their skin [2]. However, the story of Asian skin is still is still not fully understood and remains a mystery due to lack of large-scale studies and overall poor economy of the countries in Asia.

Interestingly, traditional methods of skin care and treatment sometimes challenge modern dermatology. In the background of the lack of current updated knowledge, the secrets of traditional systems will greatly enhance the effectiveness of treatment of this skin type.

Sri Lankan indigenous medicine has close affinity to Ayurveda but has its own unique properties. It has been practiced for more than 3000 years. Engravings on the rock surfaces have revealed that there was a well-expanded medical system, which had a cure for almost every illness [1]. There is fascinating historical evidence to prove that Sri Lanka was the first country which had a well-functioning hospital system [4], and their ruins are still in existence in tourist attractions such as mount Mihintale and Ritigala forest, situated in the central part of the country (Figure 1-4).

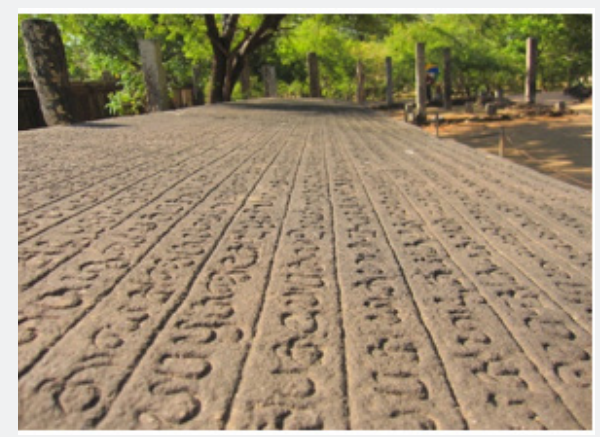

Figure 1: "Gal Potha" [stone book]; history on rock surface. 


\section{Juniper Online Journal of Dermatology \& Cosmetics}
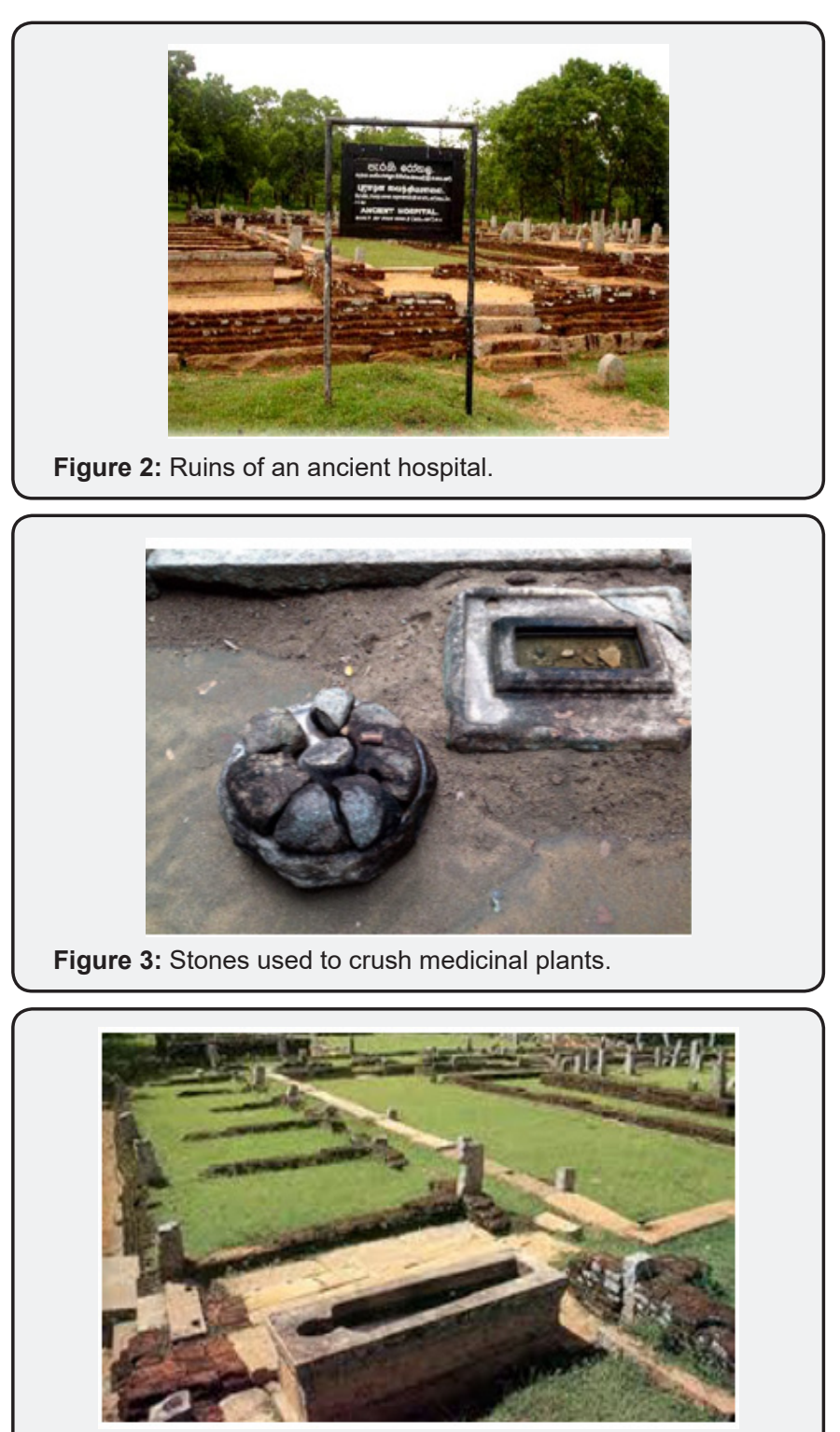

Figure 4: Medicinal tubs.

The history also revealed that the physicians were considered noble people in society and their secret prescriptions have been passed down from generation to generation within those families in the form of manuscripts. Strengthened by the influences of Buddhism, the relationship between native medicine and royalty continues in the country and even now there are people coming from these families and there are reports of them curing untreatable conditions such as terminal malignancies.

Sri Lanka has a rich collection of medicinal plants, including many endemic species. Although the island is small, it is one of the biodiversity hotspots in the world. Due to the great climate ranges within this small country, the collection of plant species also differs in each part of the country.

Cosmetology seems to be one of most demanding fields from the ancient times. Queens, princesses and their maids have used various secret herbal combinations to improve their skin beauty. In Sigiriya, the rock-based kingdom of King Kassapa, there are several rock paintings revealing the beauty of royal ladies [5].

Even now, these herbal preparations being frequently used and more popular than expensive western cosmetic products (Figure 5,6).

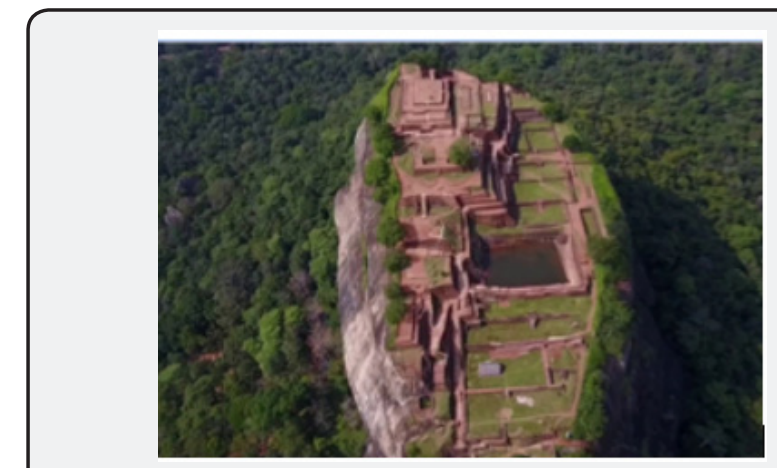

Figure 5: Rock kingdom Sigiriya.

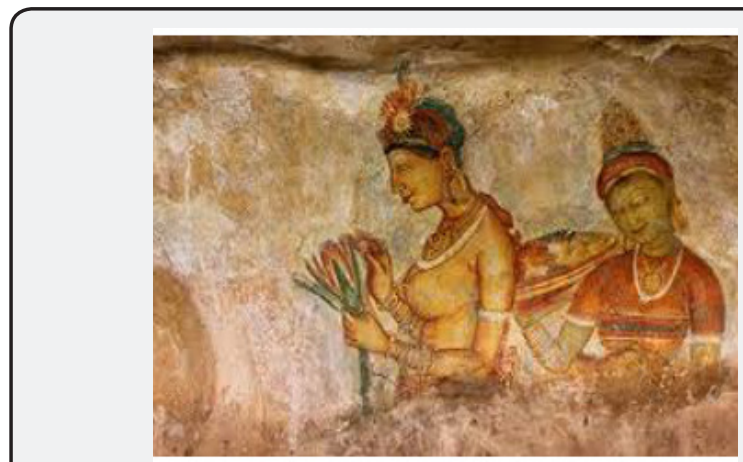

Figure 6: Rock paintings.

\section{Turmeric [Curcuma longa]}

Turmeric contains curcumin, which has anti-inflammatory and antioxidant properties, which can counteract the aging process of the skin, hence reduce wrinkles, thickening of the skin and changes of pigmentation (Figure 7) [6]. Turmeric contains fatty acids and phytosterols that help to control excessive oil of the skin. Research has shown that turmeric reduces adverse effects of UVB exposure by inhibiting matrix metalloproteinase-2 [MMP-2] following UV radiation [7].

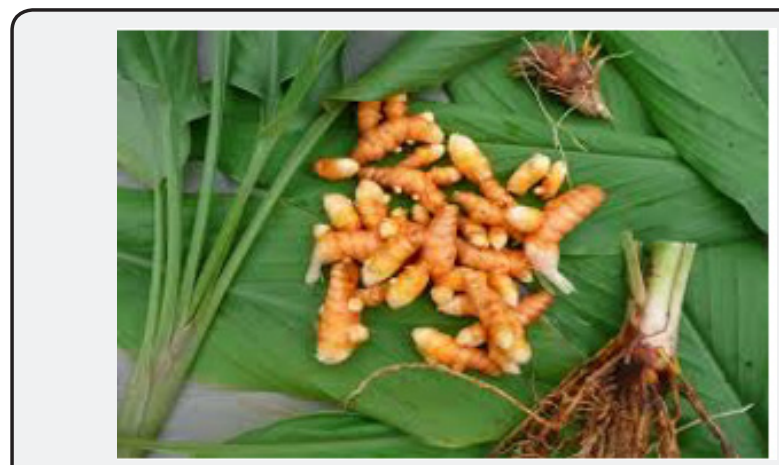

Figure 7: Turmeric.

\section{Venivel [Coscinium fenestratum]}

Venivel (Figure 8) or tree turmeric is commonly incorporated in skin care preparations. Its inner bark is dark yellow in color and has cleansing and exfoliative properties. It is a deep cleanser 
which clear clogged pores and a scrub, which exfoliates dead skin and removes excess oil [8].

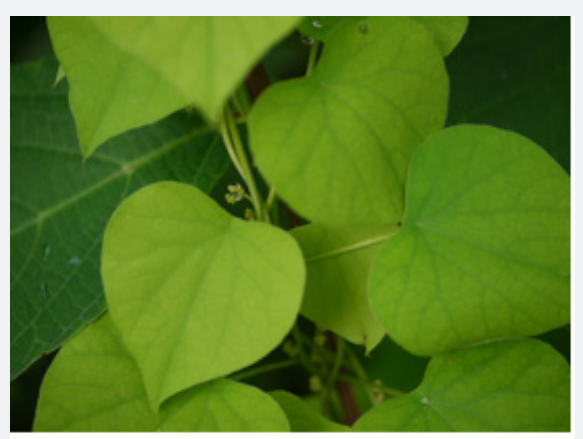

Figure 8: Venivel.

\section{Neem [ Azadirachta indica]}

Neem (Figure 9) is also called the "wonder leaf" and has amazing effects on the skin. Neem has antibacterial, antifungal anti-inflammatory and properties. The paste is formed by crushed leaves and is very popular for the treatment of acne [10]. Similarly, it is used for the treatment of skin and scalp infections.

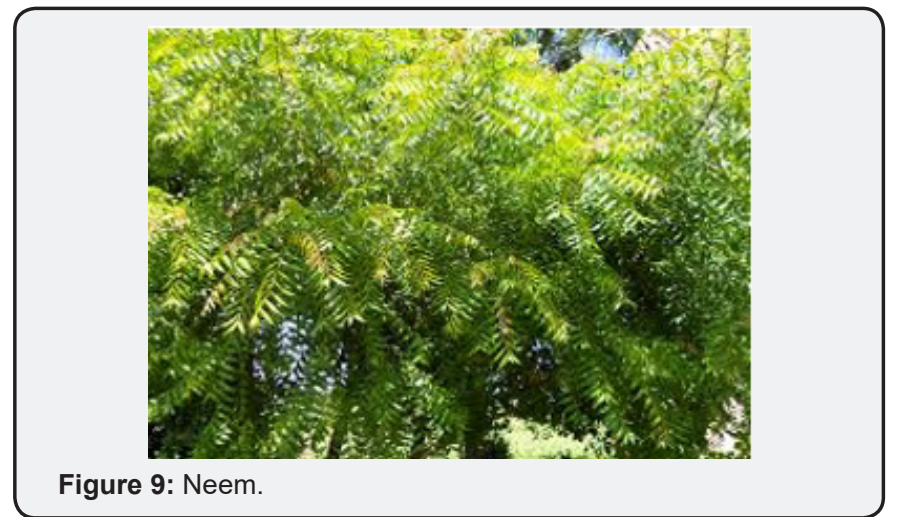

\section{White Sandalwood [Santalum album]}

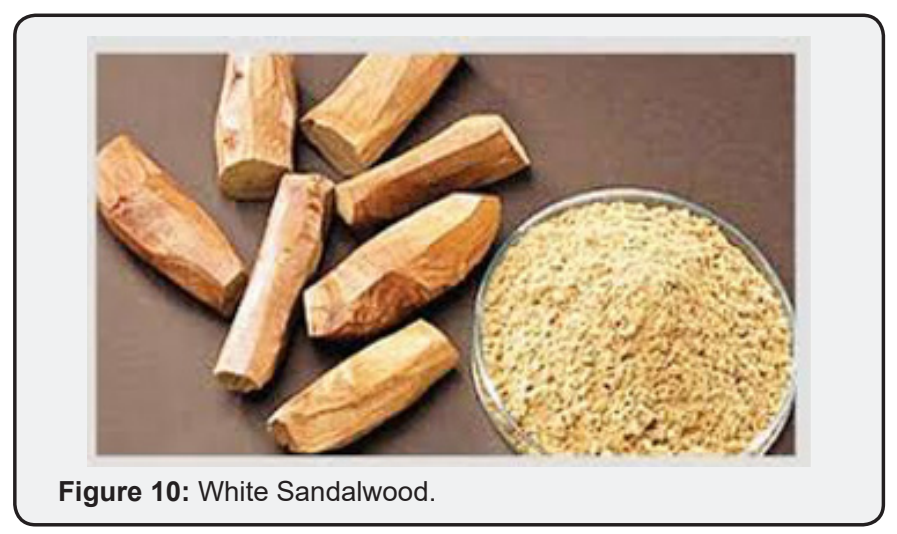

Compared to red sandalwood [Pterocarpus santalinus], (Figure 10) which has strong antibacterial properties and is commonly being used to treat skin abscesses, white sandalwood has a range of uses in cosmetology. White sandalwood paste is a good base for creams and sandalwood oil is a popular fragrance. Further, sandalwood paste is a popular remedy for the smoothing and clearing of skin. This paste with or without turmeric is a very effective for the treatment of acne as it has antibacterial and anti-inflammatory properties. It also has cooling and astringent properties and is used to treat rashes caused by excessive sweat [10].

\section{Aloe Vera [Aloe barbadensis]}

Aloe Vera (Figure 11) is a cactus group plant. Its leaves secrete a clear gel when broken, which is a popular treatment for sunburns. Aloe Vera act as an effective moisturizer for dry and cracked skin. It has vitamins, especially vitamin $\mathrm{C}$ and vitamin $\mathrm{E}$, minerals and antioxidants, hence a good ant aging remedy. Furthermore, Aloe improves collagen and reduces the visibility of stretch marks [11].

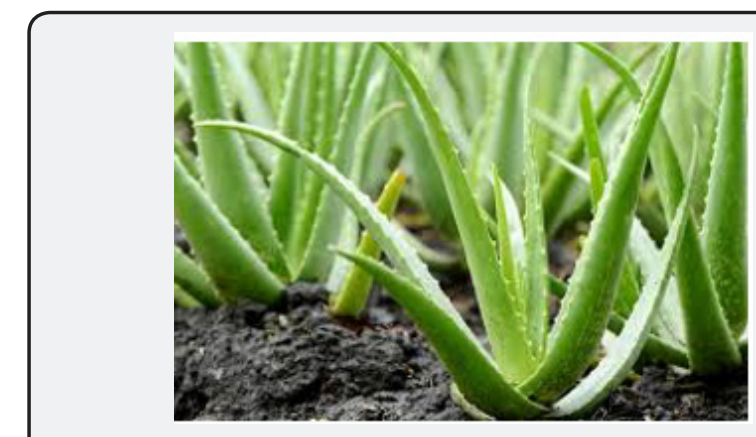

Figure 11: Aloe Vera.

\section{Kalanduru [Cyperus rotundus]}

Young plants of Kalanduru or "Nutgrass" forms a rhizome (Figure 12) which grows upwards in the soil and form a bulb-like structure. The paste formed by crushing Kalanduru yam, mixed with bee honey is an effective treatment for the removal of black heads [12].

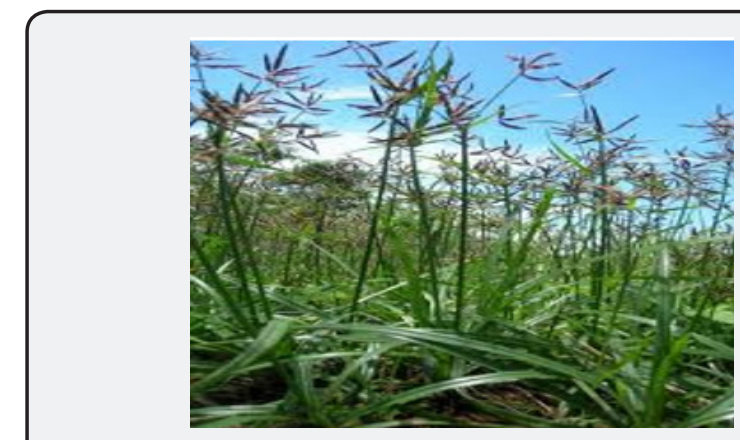

Figure 12: Kalanduru.

\section{Veralu [Elaeocarpus serratus]}

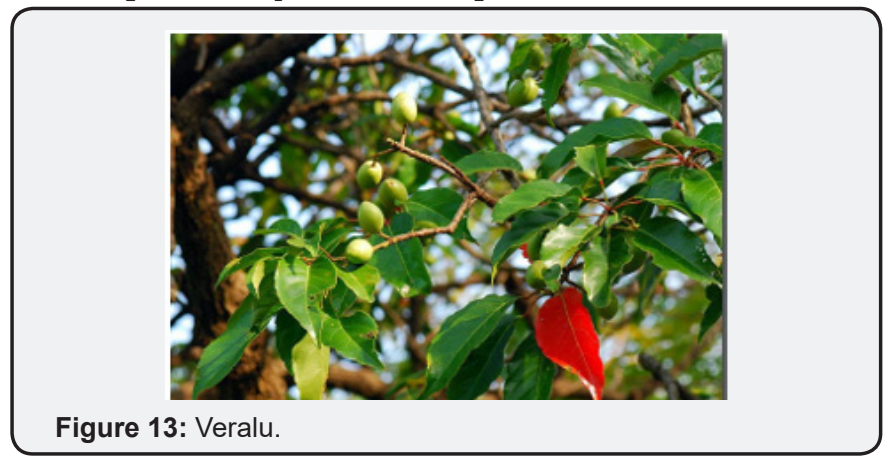


Vearlu (Figure 13) or "Ceylon olive" is a tropical fruit. Smashed Veralu leaves rubbed on scalp before bath is effective removing dandruff and to promotes hair growth.

\section{Aralu [Terminalia chebula] and Nelli [Phyllanthus emblica]}

Both Aralu seeds (Figure 14) and Nelli (Figure 15) fruits contains tannin which can interact with proteins and is known to reduce premature hair graying [13] and excessive hair loss and to improves the thickness of hair by nourishing the scalp. The juice of the Nelli fruit is mixed with lime and can be used as an instant shampoo.

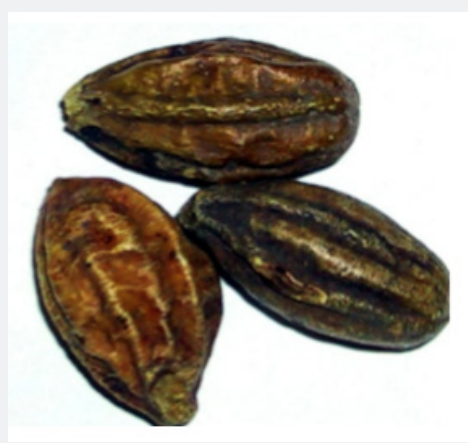

Figure 14: Aralu.

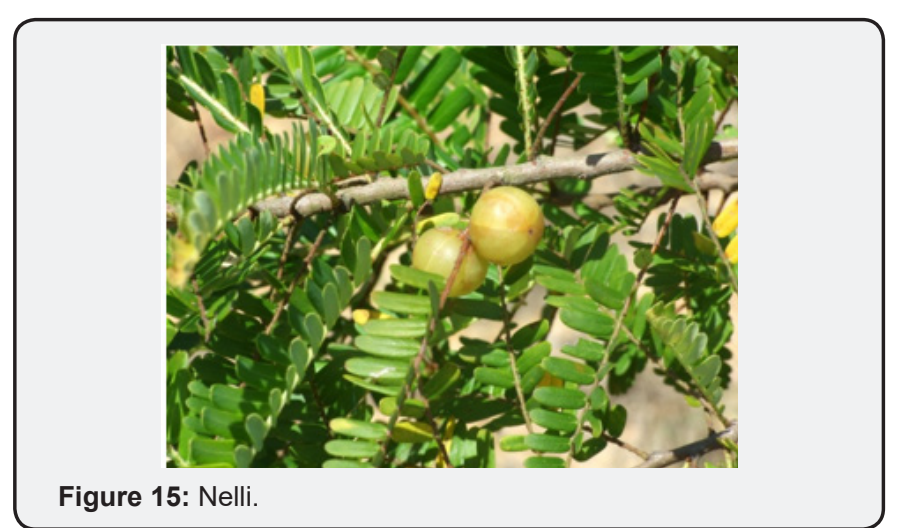

\section{Henna [Lowsonia inermis]}

Henna (Figure 16) is a natural dye for coloring of hair and temporary body tattooing. It is used as a fashion colour and for the colouring of gray hair. People are keen to achieve a range of colours can be developed by adding natural pigments such as black tea, coffee, clove or beetroot juice [14].

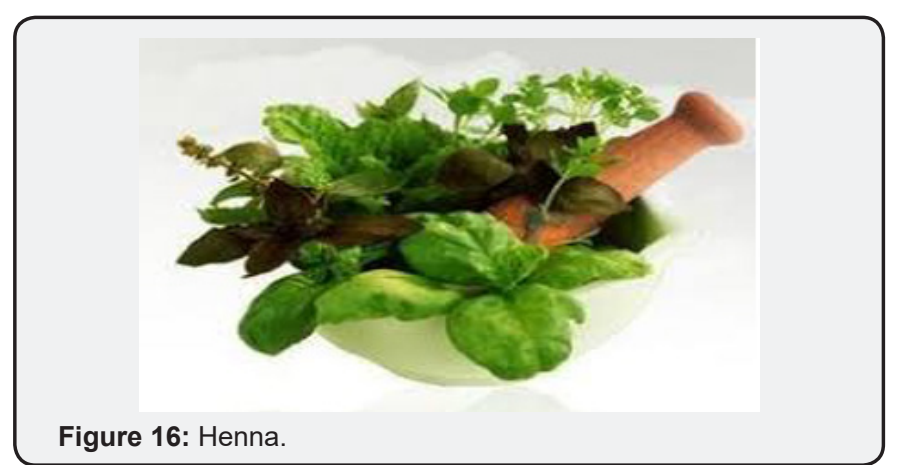

These herbs have been used perennially for centuries in Sri Lanka for the treatment of a wide range of skin conditions and occupy a central role in the system of indigenous medicine and cosmetology. Furthermore, they are used to prepare cosmetic products in Sri Lankan market and some of these products are of export standards.

\section{References}

1. Weragoda PB (1980) The traditional system on medicine in Sri lanka. J Ethnopharmacol 2(1):71-3.

2. Rawlings AV (2006) Ethic skin types: are there differences in skin structure and function? Int J Cosmet Sci 28(2): 79-93.

3. Miranda A. Farage, Kenneth W. Miller, Howard I. Maibach (2009) Textbook of Aging Skin. In: Miranda A. Farage, Kenneth W. Miller, Howard I. Maibach (Eds.) Describes recent advances in scientific, medical and technical understanding of the aging skin, Springer, UK (94): p 1019-1024.

4. Gunawardana, V DN S (2010) The Ancient Hospital Complex at Mihinthale In Sri Lanka. In: ( $3^{\text {rd }}$ edn), International congress, Society of South Asian Archaeology (SOSAA), Centre for Asian Studies, University of Kelaniya, Sri Lanka, 20-21: p. 37.

5. Fresco Paintings at Sigiriya Rock- Lankapura

6. Daily JW, Yang M, Park S (2016) Efficacy of Turmeric Extracts and Curcumin for Alleviating the Symptoms of Joint Arthritis: A Systematic Review and Meta-Analysis of Randomized Clinical Trials. J Med Food 19(8): 717-729.

7. Sumiyoshi M, Kimura Y (2009) Effects of a turmeric extract (Curcuma longa) on chronic ultraviolet B irradiation-induced skin damage in melanin-possessing hairless mice. Phytomedicine 16(12):1137-43.

8. Potikanond S, Chiranthanut N, Khonsung P, Teekachunhatean S (2015) Cytotoxic Effect of Coscinium fenestratum on Human Head and Neck Cancer Cell Line (HN31). Evid Based Complement Alternat Med: 8.

9. Schumacher M, Cerella C, Reuter S, Dicato M, Diederich M (2011) Anti-inflammatory, pro-apoptotic, and anti-proliferative effects of a methanolic neem (Azadirachta indica) leaf extract are mediated via modulation of the nuclear factor-кB pathway. Genes Nutr 6(2): 149160.

10. Ronald L Moy, Corey Levenson (2017) Sandalwood Album Oil as a Botanical Therapeutic in Dermatology. J Clin Aesthet Dermatol 10(10): 34-39.

11. Seyyed Abbas Hashemi, Seyyed Abdollah Madani, and Saied Abendiankenari (2015) The Review on Properties of Aloe Vera in Healing of Cutaneous Wounds. Biomed Res Int: 6

12. Pirzada AM, Ali HH, Naeem M, Latif M, Bukhari AH, et al. (2015) Cyperusrotundus L: Traditional uses, phytochemistry, and pharmacological activities. J Ethnopharmacol. 174: 540-560.

13. Anwesa Bag, Subir Kumar Bhattacharyya, and Rabi Ranjan Chattopadhyay (2013) The development of Terminalia chebula Retz. (Combretaceae) in clinical research. Asian Pac J Trop Biomed 3(3): 244-252.

14. Vijender Singh, Mohammed Ali, and Sukirti Upadhyay (2015) Study of colouring effect of herbal hair formulations on graying hair. Pharmacognosy Res 7(3): 259-262. 
This work is licensed under Creative Commons Attribution 4.0 License DOI: 10.19080/JOJDC.2018.01.555558
Your next submission with Juniper Publishers will reach you the below assets

- Quality Editorial service

- Swift Peer Review

- Reprints availability

- E-prints Service

- Manuscript Podcast for convenient understanding

- Global attainment for your research

- Manuscript accessibility in different formats

( Pdf, E-pub, Full Text, Audio)

- Unceasing customer service

Track the below URL for one-step submission https://juniperpublishers.com/online-submission.php 